[From the Laboratories of Physiological Chemistry of the University of ILIINOIS AND OF JEFFERSON MEDICAL, COLLEGE.]

\title{
STUDIES ON WATER DRINKING. XVIII. ON THE RELATION BETWEEN WATER INGESTION AND THE AMMONIA, PHOSPHATE, CHLORIDE AND ACID EXCRETION.
}

By D. W. Wilson and P. B. Hawk.

Received June 20, 1914.

In the course of a former investigation carried out by one of us ${ }^{1}$ it was demonstrated that the ingestion of water was followed by an increased excretion of urinary ammonia and that the extent of this increase for any given subject was directly proportional to the volume of water ingested. The actual increase in the ammonia output varied, however, for different individuals. The relation between the water ingestion and the increased ammonia output as determined for the two subjects of that experiment was as follows:

Subject W.

$\overbrace{\begin{array}{c}\text { Expt. } \mathrm{I}_{H_{2} \mathrm{O}} \\ \text { Copious } \mathrm{H}_{2} \mathrm{O}\end{array}}^{\text {Expt II. }}$

I : $1.8 \mathrm{I}$

I : 1.75

\begin{tabular}{|c|c|}
\hline \multicolumn{2}{|c|}{ Subject E. } \\
\hline $\begin{array}{l}\text { Expt. III. } \\
\text { Copious } \mathrm{H}_{2} \mathrm{O}\end{array}$ & $\begin{array}{c}\text { Expt. IV. } \\
\mathrm{NH}_{\text {s }} \text { inc. (cop.) }\end{array}$ \\
\hline Moderate $\mathrm{H}_{2} \mathrm{O}$ & NHs inc. (mod.) \\
\hline$I: 2.66$ & $I: 2.54$ \\
\hline
\end{tabular}

The above data indicate that when the water ingestion of Subject $W$ was increased from a value of $I$ to a value of $I .8 I$ that the ammonia excretion simultaneously rose from a value of $I$ to a value of 1.75 . In the case of Subject $E$ the water and ammonia ratios were $I: 2.66$ and $I: 2.54$. The increased output of ammonia under the influence of water ingestion was interpreted as indicating a stimulation of gastric secretion.

In order to make a further study of the water-ammonia relationship, using other subjects, the present investigation was planned. The relationship of the ammonia output to the urinary chloride, phosphate and acid excretion was also included.

The general plan of the experiment was similar to that of other experiments previously reported. ${ }^{2,3}$ Two normal young men served as subjects. The diet was simple in character and uniform from day to day. The actual daily diet as fed was as follows:

Graham crackers....... 300 grams

Milk (whole) .......... I 200 cc.

Peanut butter........ 45 grams

Water (distilled)....... $300 \mathrm{cc}$.

Butter............. 75 grams

The experiment was divided into five periods as follows: preliminary (3-5 days), moderate water drinking (10 days), intermediate (5 days), copious water drinking ( 5 days), final ( 5 days).

1 Wills and Hawk, This Journal, 36, 158 (1914).

2 Mattill and Hawk, Ibid., 33, 1978 (I9I I).

${ }^{3}$ Fowler and Hawk, Exp. Med., 12, 388 (IgIo). 
During the preliminary, intermediate and final periods Subject $\mathrm{C}$ ingested $400 \mathrm{cc}$. water per day between meals, whereas Subject V drank $600 \mathrm{cc}$. During the moderate water drinking period each subject took $500 \mathrm{cc}$. water additional at each meal. Thus the total daily water ingestion of $\mathrm{C}$ during this period was 2200 cc., whereas $\mathrm{V}$ drank $2400 \mathrm{cc}$. In the period of high water intake each subject drank $850 \mathrm{cc}$. water at each

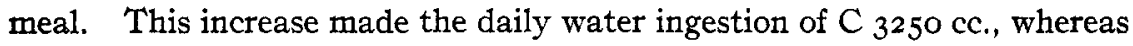
that of $\mathrm{V}$ was $345^{\circ} \mathrm{cc}$.

Ammonia and acidity were determined by Folin's methods. The phosphates were determined by the uranium method, whereas chlorides were estimated by the Dehn-Clark procedure. ${ }^{1}$

\section{Discussion.}

Chlorides and Phosphates. -The excretion of chlorides showed small variations. Both subjects excreted less during the water periods and showed a lower output with moderate than with copious water ingestion. The averages for the preliminary period ( 6.6 and 6.45 grams) indicate a low chloride ingestion, which may account for the small variations observed in the different experimental periods. With a low chloride intake there would be less liability of retention and flushing out of the tissues with the increased water ingestion. In fact the data indicate a reverse tendency. On the first day of each period of moderate and copious water ingestion there was a retention instead of a loss. This undoubtedly was due to the efforts of the body to maintain the normal osmotic pressure in its various fluids. In most cases there was a marked retention of water, and as distilled water was ingested, a considerable retention of inorganic salts was necessary. The phosphates were excreted in normal amounts in order to eliminate acids formed from metabolic procedures, so that the first source of material for maintenance of osmotic pressure would be the ingested chlorides.

The most marked example of the chloride retention was in the case of Subject V. On the Ist day of the intermediate period the chloride output was 8.2 g., whereas on the two following days in which copious volumes of water were ingested the chloride sank to 4.7 and 4.0 g., respectively, values only about $50 \%$ as great as that previously obtained. The intermediate period showed an increased chloride output due to the loss of water when the water ingestion was decreased. The use of distilled water with a low ingestion of inorganic salts may easily account for the lack of greater variations in the chloride output than those observed.

Ammonia and Acidity.-The variations in the ammonia output as influenced by the ingestion of water are readily apparent from an examination of the tables. Increased water ingestion was followed by an in-

${ }^{1}$ See Hawk's "Practical Physiological Chemistry," fourth edition, 1912, p. 417. 
creased excretion of urinary ammonia. Subject $V$ gave a normal ammonia value of $0.26 \mathrm{~g}$. in the preliminary period which value was increased to $0.32 \mathrm{~g}$. when a moderate increase in the water ingestion was made. The maximum ammonia value was $0.33 \mathrm{~g}$. and was obtained during the copious water period. The ammonia data of Subject $\mathrm{C}$ showed greater variations, but with the same general tendency. The preliminary period gave an average ammonia excretion of $0.29 \mathrm{~g}$., which underwent an increase of $0.37 \mathrm{~g}$. during the period of moderate water intake. The average of the intermediate period was slightly lower than that of the preliminary period ( $0.26 \mathrm{~g}$.), but rose again upon copious water ingestion to 0.34 g., a value which was somewhat lower than the value yielded by this subject upon the ingestion of moderate quantities of water. The final period gave a minimum average of $0.25 \mathrm{~g}$.

Subject $\mathrm{C}$ showed an increased excretion of acid and phosphates during the water drinking period with maxima during the moderate water ingestion. Subject V showed a decreased excretion of both constituents in both cases.

The increased excretion of ammonia as observed with both subjects and the increased excretion of acids and phosphates in the case of Subject $\mathrm{C}$ indicate to us an increased cell metabolism, causing a formation of acid products which are partly neutralized by ammonia formation and partly cause increased acid phosphates in the urine. Various experiments in this and other laboratories have shown increased total nitrogen excretion, and one of us has recently observed ${ }^{1}$ an increased neutral sulfur output after ingestion of considerable quantities of water. It has been suggested that neutral sulfur is a product of cellular metabolism. The increase of total nitrogen and neutral sulfur substantiates our assumption that the observed increased excretion of ammonia, phosphates and increased urinary acidity is due to stimulated cell metabolism caused by ingestion of considerable quantities of water.

A complication which undoubtedly makes less apparent any variations which are produced, is the necessity of maintenance of osmotic pressure by the body. This calls for considerable amounts of dissolved solids drawn from the tissues by the distilled water ingested. As inorganic salts are the most efficient means of developing osmotic pressure, as well as the most available, they would be most in demand and thus cause a retention of the constituents with which we are dealing. This retention undoubtedly occurs in all the water periods of the experiment and is sufficient in the case of Subject $V$ to mask any tendency toward increased excretion of the acid phosphates. The same consideration probably explains why the values $\left(\mathrm{NH}_{3}\right.$, acidity and phosphates) for the copious water periods were lower than the values for the moderate water periods.

1 Fowler and Hawk, Unpublished. 
The retention of even small volumes of distilled water by the body would call for a marked retention of inorganic salts. For example, a retention of nearly $3 \mathrm{~g}$. of inorganic salts, calculated as $\mathrm{NaCl}$, would be necessary to render $300 \mathrm{cc}$. of distilled water isotonic. Calculated as

Subject C.

\begin{tabular}{|c|c|c|c|c|c|}
\hline Day. & $\begin{array}{c}\text { Urine. } \\
\text { Voiume, } \\
\text { Ce. }\end{array}$ & $\begin{array}{c}\mathrm{NH}_{3} \\
\text { N. } \\
\text { Grams. } \\
\text { iminary. }\end{array}$ & $\begin{array}{l}\text { Acidity } \\
\text { Ce. N/10. } \\
\text { NaOH. }\end{array}$ & $\begin{array}{l}\mathrm{P}_{2} \mathrm{O}_{3} \\
\text { Grams. }\end{array}$ & $\begin{array}{l}\text { Chloride } \\
\text { Grams. } \\
\text { NaCl. }\end{array}$ \\
\hline $4 \ldots \ldots \ldots \ldots \ldots \ldots$ & 720 & 0.29 & 252.6 & I.5O & 6.78 \\
\hline $5 \ldots \ldots \ldots \ldots \ldots \ldots$ & 620 & 0.26 & $235 \cdot 4$ & I. 94 & 6.57 \\
\hline $6 \ldots \ldots \ldots \ldots \ldots \ldots$ & 615 & $0.3 \mathrm{I}$ & 300.2 & 1.93 & 6.57 \\
\hline Average.......... & $65 \mathrm{I}$ & 0.29 & 262.7 & I. 79 & 6.64 \\
\hline \multicolumn{6}{|c|}{ Moderate water. } \\
\hline $7 \ldots \ldots \ldots \ldots \ldots \ldots$ & 995 & 0.38 & $324 \cdot 7$ & I.88 & 5.44 \\
\hline $8 \ldots \ldots \ldots \ldots \ldots \ldots$ & 1465 & 0.37 & 324.4 & 2.24 & 6.60 \\
\hline $9 \ldots \ldots \ldots \ldots \ldots \ldots$ & 1215 & $0.4 \mathrm{I}$ & 343.8 & I. 99 & 5.96 \\
\hline Iо $\ldots \ldots \ldots \ldots \ldots \ldots$ & 1620 & 0.36 & $28 \mathrm{I} .0$ & 2.24 & $5 \cdot 98$ \\
\hline $11 \ldots \ldots \ldots \ldots \ldots \ldots$ & 2040 & 0.38 & 242.9 & I. 97 & $6.3 \mathrm{I}$ \\
\hline$\llbracket 2 \ldots \ldots \ldots \ldots \ldots \ldots$ & 2050 & 0.37 & 242.2 & I. 97 & 6.04 \\
\hline ז $3 \ldots \ldots \ldots \ldots \ldots \ldots$ & I 800 & 0.35 & $265 \cdot 7$ & I. 97 & 6.31 \\
\hline$x_{4} \ldots \ldots \ldots \ldots \ldots \ldots$ & 2230 & 0.34 & $224 \cdot 2$ & I. 93 & 6.54 \\
\hline $15 \ldots \ldots \ldots \ldots \ldots \ldots$ & 2330 & 0.38 & 346.0 & I.90 & $7 \cdot 14$ \\
\hline I6.................. & 1930 & 0.38 & 280.5 & 1.98 & 6.29 \\
\hline Average........... & 1768 & 0.37 & 287.5 & 2.01 & 6.26 \\
\hline \multicolumn{6}{|c|}{ Intermediate. } \\
\hline $17 \ldots \ldots \ldots \ldots \ldots \ldots$ & 860 & 0.29 & 219.6 & I. 84 & 6.64 \\
\hline I $8 \ldots \ldots \ldots \ldots \ldots \ldots \ldots$ & 675 & 0.28 & 289.3 & I. 88 & $5 \cdot 92$ \\
\hline $19 \ldots \ldots \ldots \ldots \ldots \ldots$ & 700 & 0.28 & 24 I. 8 & I. 88 & 5.96 \\
\hline $20 \ldots \ldots \ldots \ldots \ldots \ldots$ & 770 & 0.24 & 200.6 & I. 88 & 8.00 \\
\hline $21 \ldots \ldots \ldots \ldots \ldots \ldots$ & 710 & o. I9 & 182.9 & I. 86 & $7 \cdot 30$ \\
\hline Average.......... & 743 & 0.26 & 226.8 & I. 87 & 6.76 \\
\hline \multicolumn{6}{|c|}{ Copious water. } \\
\hline $22 \ldots \ldots \ldots \ldots \ldots \ldots$ & 2900 & 0.33 & 253.4 & 2.09 & 6.34 \\
\hline $23 \ldots \ldots \ldots \ldots \ldots \ldots \ldots$ & 2670 & 0.36 & $234 \cdot 5$ & I.6I & $5 \cdot 38$ \\
\hline $24 \ldots \ldots \ldots \ldots \ldots \ldots$ & 3360 & 0.35 & $244 \cdot 9$ & 1.97 & 6.97 \\
\hline $25 \ldots \ldots \ldots \ldots \ldots \ldots$ & 3210 & 0.35 & 255.8 & I. 96 & $6.6 \mathrm{x}$ \\
\hline $26, \ldots \ldots \ldots \ldots \ldots$, & 3300 & 0.32 & 228.6 & I. 86 & $7 \cdot 4 \mathrm{I}$ \\
\hline Average.......... & 3088 & 0.34 & $243 \cdot 4$ & 1.90 & 6.54 \\
\hline \multicolumn{6}{|c|}{ Final. } \\
\hline $27 \ldots \ldots \ldots \ldots \ldots \ldots \ldots$ & 920 & 0.23 & 233.5 & I. 70 & 6.77 \\
\hline $28 \ldots \ldots \ldots \ldots \ldots \ldots$ & 820 & 0.26 & $259 \cdot 5$ & 1.75 & 5.78 \\
\hline $29 \ldots \ldots \ldots \ldots \ldots \ldots$ & 835 & 0.26 & $279 . I$ & I. 88 & 6.13 \\
\hline $30 \ldots \ldots \ldots \ldots \ldots \ldots$ & 810 & 0.25 & $292 \cdot 7$ & I.94 & 6.44 \\
\hline $3 \mathbf{x} \ldots \ldots \ldots \ldots \ldots \ldots$, & 850 & 0.25 & $244 \cdot 4$ & I. 94 & $7 \cdot 32$ \\
\hline Average............ & 847 & 0.25 & 26 I. 8 & I. 84 & 6.49 \\
\hline
\end{tabular}


SUBJfict V.

Day.

$\begin{array}{cc}\begin{array}{c}\text { Urine. } \\ \text { Volume. }\end{array} & \begin{array}{c}\text { NHs } \\ \text { Ce. } \\ \text { Grams. }\end{array} \\ \text { Preliminary. }\end{array}$

\begin{tabular}{|c|c|c|c|c|}
\hline $4 \ldots \ldots \ldots \ldots \ldots \ldots$ & 740 & 0.22 & 254.9 & 1.72 \\
\hline $5 \ldots \ldots \ldots \ldots \ldots \ldots$ & 1425 & 0.27 & 219.3 & 1.95 \\
\hline $6 \ldots \ldots \ldots \ldots \ldots \ldots$ & 890 & $0.3 \mathrm{I}$ & 268.0 & 1.93 \\
\hline $7 \ldots \ldots \ldots \ldots \ldots \ldots$ & 665 & 0.26 & 265.3 & 1.89 \\
\hline $8 \ldots \ldots \ldots \ldots \ldots \ldots$ & 690 & 0.24 & 248.6 & I. 84 \\
\hline
\end{tabular}

Moderate water.

\begin{tabular}{|c|c|c|c|c|c|}
\hline $9 \ldots \ldots \ldots \ldots \ldots \ldots$ & 2110 & 0.31 & 258.9 & 1.77 & 5.07 \\
\hline 10.................... & 2210 & 0.31 & $240 . I$ & 1.88 & 6.06 \\
\hline ı1................. & 1620 & 0.34 & 245.0 & 1.82 & $5 \cdot 70$ \\
\hline $12 \ldots \ldots \ldots \ldots \ldots \ldots$ & 1970 & $0.2 \mathrm{I}$ & 159.6 & 1.02 & 6.73 \\
\hline s $3 \ldots \ldots \ldots \ldots \ldots$ & 2380 & 0.33 & 204.7 & 1.45 & 6.65 \\
\hline $\mathbf{1 4} \ldots \ldots \ldots \ldots \ldots \ldots$ & 2550 & 0.29 & 219.4 & $x .89$ & 6.72 \\
\hline $15 \ldots \ldots \ldots \ldots \ldots \ldots$ & 2165 & 0.38 & 238.2 & 1.66 & $5 \cdot 72$ \\
\hline $16 \ldots \ldots \ldots \ldots \ldots \ldots$ & 2635 & 0.34 & 201.6 & 1.43 & 6.73 \\
\hline $17 \ldots \ldots \ldots \ldots \ldots \ldots$ & 2205 & 0.36 & 245.6 & I. 47 & $5 \cdot 76$ \\
\hline $18 \ldots \ldots \ldots \ldots \ldots \ldots$ & 2410 & 0.29 & 216.1 & $x .64$ & $5 \cdot 98$ \\
\hline verage........... & 2226 & 0.32 & 222.9 & 1.60 & 6.11 \\
\hline
\end{tabular}

Intermediate.

$\begin{array}{rlllll}19 \ldots \ldots \ldots \ldots \ldots \ldots \ldots & 1230 & 0.25 & 201.6 & 1.56 & 7.26 \\ 20 \ldots \ldots \ldots \ldots \ldots \ldots & 1025 & 0.26 & 240.9 & 1.78 & 5.88 \\ 21 \ldots \ldots \ldots \ldots \ldots \ldots & 1000 & 0.25 & 240.4 & 1.71 & 6.40 \\ 22 \ldots \ldots \ldots \ldots \ldots \ldots & 1195 & 0.24 & 220.9 & 1.96 & 7.23 \\ 23 \ldots \ldots \ldots \ldots \ldots \ldots & 1670 & 0.23 & 233.7 & 1.92 & 8.21 \\ \text { Average } \ldots \ldots \ldots \ldots & 1224 & 0.26 & 229.3 & 1.79 & 7.00\end{array}$

Copious water.

\begin{tabular}{|c|c|c|c|c|c|}
\hline $24 \ldots \ldots \ldots \ldots \ldots \ldots$ & 3400 & 0.35 & 224.9 & 1.65 & $4 \cdot 70$ \\
\hline $25 \ldots \ldots \ldots$ & 3140 & 0.35 & 226.0 & 1.47 & 4.02 \\
\hline $26 \ldots \ldots \ldots \ldots \ldots \ldots$ & 3600 & $0.3 \mathrm{I}$ & 207.1 & 1.77 & 6.91 \\
\hline $27 \ldots \ldots \ldots \ldots \ldots \ldots$ & 3860 & 0.33 & 199.2 & 1.63 & 8.38 \\
\hline $28 \ldots \ldots \ldots \ldots \ldots \ldots \ldots$ & 3660 & 0.33 & 212,1 & 1.67 & 6.91 \\
\hline Average. . & 3532 & 0.33 & 213.8 & 1.64 & 6.18 \\
\hline
\end{tabular}

Final.

\begin{tabular}{|c|c|c|c|c|c|}
\hline $29 \ldots \ldots \ldots \ldots \ldots \ldots$ & 920 & 0.25 & 232.2 & 1.63 & 6.12 \\
\hline $30 \ldots \ldots \ldots \ldots \ldots \ldots$ & 1240 & 0.27 & 223.5 & 1.82 & 6.69 \\
\hline $31 \ldots \ldots \ldots \ldots \ldots \ldots$ & 835 & 0.28 & $271 \cdot 7$ & 1.72 & 5.25 \\
\hline $32 \ldots \ldots \ldots \ldots \ldots$ & 815 & 0.23 & 217.6 & I. 75 & $5 \cdot 53$ \\
\hline $33 \ldots \ldots \ldots \ldots \ldots \ldots$ & Ioro & 0.22 & 208.7 & $\mathrm{I} .84$ & 6.89 \\
\hline Average......... & 964 & 0.25 & 230.7 & I. 75 & 6.10 \\
\hline
\end{tabular}


phosphates, the value would be higher. A retention of double that volume was indicated by variations in body weights of the subjects in the different periods.

Considering the variations in the excretion and retention which would be caused by the variations in the water content of the body, the small differences which we have obtained in our experiments are much more significant, for our increases in ammonia, phosphate and acid output have been evident in spite of the tendency to retention and obscurity. In other experiments in this laboratory, where ordinary tap water has been used, the variations were much more pronounced. This was undoubtedly favored by the presence of salts in the water which made it less necessary for the body to supply the necessary material for development of sufficient osmotic pressure.

It will be observed that the increase in urinary ammonia which followed the increased water intake by the subjects of these test's was not proportional to the volume of water ingested. This lack of relationship is easily explained on the basis of certain experiments now in progress by one of us. ${ }^{1}$ In the tests mentioned the introduction of distilled water into the empty stomach causes an increased flow of gastric juice but the increased flow is, in some cases at least, in no way proportional to the volume of water introduced into the stomach. Inasmuch as we believe the ammonia output, under such conditions, is regulated to a large degree by the amount of acid entering the intestine, the non-parallelism of the water intake and the ammonia output may be logically explained.

PhILAdelpeta, PA.

[From the Laboratories of Physiological Chemistry of the University of ILLINOIS AND JEFFERSON MEDICAL COLIEGE.]

\section{STUDIES ON WATER DRINKING. XIX. INTESTINAL PUTRE- FACTION AS INFLUENCED BY THE INGESTION OF SOFTENED AND DISTILLED WATERS.}

By C. P. SHarwin and P. B. Hawr.

Received June 12, 1914.

Investigations already reported by one of us ${ }^{1}$ indicated that the drinking of copious (I000 cc.) or moderate $(500 \mathrm{cc}$.) volumes of water with meals decreased intestinal putrefaction as measured by the urinary indican output, and that copious water drinking caused a more pronounced lessening of the putrefactive processes than did the moderate water drinking. Softened water was employed in the experiments in question. In the present instance the influence of both distilled and softened water was studied.

The investigation here reported embraced two experiments, young men

1 Rehfuss, Bergeim and Hawk, Unpublished. 